Bangladesh J. Zool. 42(2): 237-249, 2014

\title{
FOOD AND FEEDING HABITS OF WHITE-THROATED KINGFISHER (HALCYON SMYRNENSIS) IN BANGLADESH
}

\author{
Habibon Naher ${ }^{1}$ and Noor Jahan Sarker \\ Department of Zoology, University of Dhaka, Dhaka-1000, Bangladesh
}

\begin{abstract}
Food items, preying and feeding activities of white-breasted Kingfisher, Halcyon smyrnensis were studied from September 2008 to September 2011 at Nikunja-1 in Dhaka City Corporation area. A total of 16 species of food items were recorded from the observation. Fishes (more than 60\%) were mostly preferred item. The highest preference was fry of Labeo rohita (30.6\%). They highly preferred the species belonging to the Family Cyprinidae and Order Cypriniformes. The length of the food items varied from 2.0 to $12.3 \mathrm{~cm}$. Surface dweller species $(85.8 \%)$ was highly preferred. During preying, they used 0.3 to $2.25 \mathrm{~m}$ height, among which the highest preference was $0.9 \mathrm{~m} \mathrm{(32 \% ).} \mathrm{H.} \mathrm{smyrnensis} \mathrm{targeted} \mathrm{the}$ food items before catching while they took $9 \mathrm{sec}$ to $15 \mathrm{~min} 17 \mathrm{sec}$. After catching they either engulfed the prey immediately or hold it at their beak for 2 sec to 30 min $30 \mathrm{sec}$ before engulfing. Bamboos found in the water body were mostly preferred $(65.9 \%)$ as perching places during preying.
\end{abstract}

Key words: Food preference, preying height, Kingfisher, Halcyon smyrnensis.

\section{INTRODUCTION}

The White-breasted or White-throated Kingfisher (Halcyon smyrnensis, Linnaeus 1758) are resident throughout much of the Indian subcontinent (Grimmett et al. 1998).

Reza et al. (2003) studied the status and density of Kingfishers in the Sundarbans mangrove forest of Bangladesh. Some causal information is available about the kingfishers of Bangladesh (Ahsan and Saeed 1990, Islam et al. 1999, Sarker 1989). Except these observations nothing is known about the Kingfishers in Bangladesh. Therefore, an attempt was made to study the food items, preying and feeding activities of White-breasted Kingfisher (Halcyon smyrnensis) in Bangladesh.

\section{MATERIAL AND METHODS}

The study was undertaken on food items, preying and feeding activities of White-breasted Kingfisher, H. smyrnensis in Bangladesh' from September 2008 to September 2011. The study was carried out in Nikunja-1, Uttara, Dhaka, Bangladesh (Fig.1). This area is under the Dhaka City Corporation and on the west side of Dhaka Airport highway. There are two Lakes, one on the east $\left(23^{\circ} 49^{\prime} 14.81^{\prime \prime}\right.$ to $23^{\circ} 49^{\prime} 36.04^{\prime \prime} \mathrm{N}$ latitudes and $90^{\circ} 25^{\prime} 02.38^{\prime \prime}$ to $90^{\circ} 25^{\prime} 12.30^{\prime \prime} \mathrm{E}$

${ }^{1}$ Author for correspondence: Department of Zoology, Jagannath University, Dhaka-1100, Bangladesh. 
longitudes) and the other on the west side $\left(23^{\circ} 49^{\prime} 26.33^{\prime \prime}\right.$ to $23^{\circ} 49^{\prime} 30.77^{\prime \prime} \mathrm{N}$ latitudes and $90^{\circ} 24^{\prime} 55.60^{\prime \prime}$ to $90^{\circ} 24^{\prime} 59.82^{\prime \prime}$ E longitudes) of the Nikunja-1 residential area. The size of the eastern lake is $668.5 \mathrm{X} 17.07 \mathrm{~m}$ and western lake is $218.13 \times 75.05 \mathrm{~m}$. The northern and southern sides of Nikunja-1 are surrounded by Nikunja-2 residential area and Dhaka Cantonment Golf field respectively.

Food habits were observed at least once a week in non-breeding season and thrice in a week in breeding season. The birds were watched from dawn to dusk as the species are diurnal. During preying, the food species especially fishes was identified immediately by a pair of binoculars and telescope. The length and breadth of fishes were assumed during preying and photograph and video clips were used to identify keenly. But in case of arthropods, direct observation was made by sample collection and identified the species with the support of a senior entomologist. The length, breadth of larvae and nymph of different arthropods, habitat, feeding habits and breeding seasons of those arthropods were noted down from Border et al. (1981). The using perching places by the birds during preying were also noted. The height of related perching places was visually assumed. The spending time with the respective height of perching places in preying of each food item was counted by a digital stop watch to find out the variation of spending time to catch a prey of different heights. The spending time to catch and engulf a food item was counted by a digital stop watch to find out the variation of spending time to catch and engulf a large and small sized food.

\section{RESULTS AND DISCUSSION}

Food items: H. smyrnensis preyed on 16 species which comprised of nine species of arthropods, five freshwater fishes, one amphibian and one reptile (Table 1). Some large size insects (e.g. giant water bugs, aquatic beetles, caddies fly,) found on water surface or the floating vegetation (water hyacinth, Pistia sp.) also preyed by the birds. Almost same observation was made by the authors in India (Jerdon 1982, Whistler 1986, Woodcock 1980). This bird is well known for its versatile food and feeding habits (Ali and Ripley 1983, Mukherjee 1975). Islam and Kamruzzaman (2008) reported that it fed largely on insects such as grasshoppers, crickets, mantises, scarabs and other beetles, ants, winged termites, locusts and dragonflies. They also mentioned that it also hunt fish, crabs, mice and birds. Wikipedia (2010) reported that it mainly hunt large crustaceans, insects, earthworms, rodents, snakes, fish, frogs and small birds such as the Oriental White-eye, chick of a red-wattled lapwing, sparrows and munias. Ali and Ripley (1983) reported that the food consisted of largely insects 


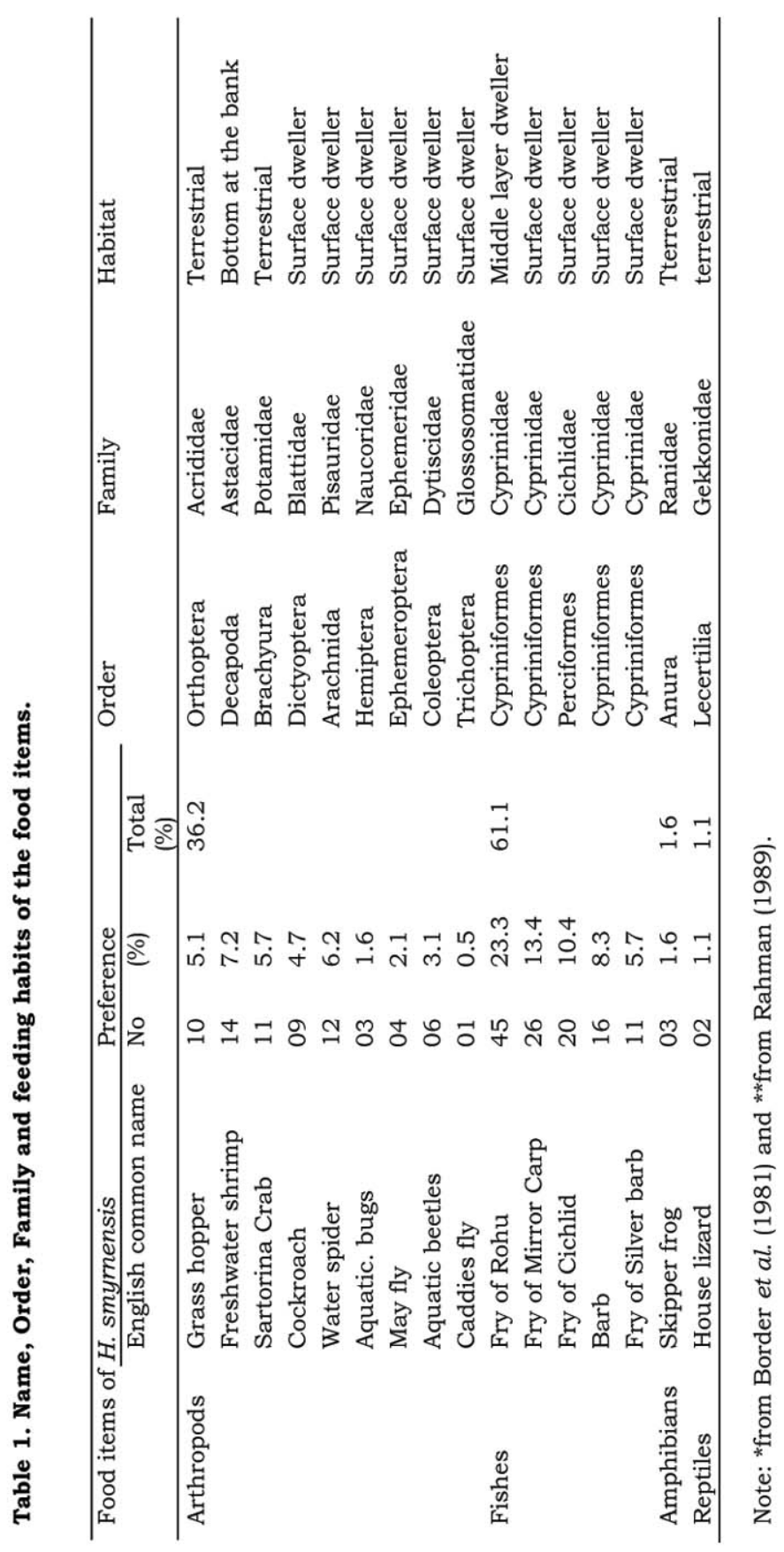


and secondarily of fishes. Moreover, they mentioned that the food also consisted of frogs and lizards (Mabuia and Calotes, etc.), mice and birds like fledgling sparrows, adult white-eye and munias and red-wattled lapwing chick. Large insects, fish, frogs, lizards, young birds and mice form a major part of their diet in India (Ali 1996). Asokan et al. (2009) reported that the diet consisted of arthropods primarily in addition with crab, fishes, amphibians and reptiles.

Almost similar findings were also noticed about kingfishers by different workers of different countries (e.g., Ewans 1989, EcoIndia 2008, Arkive 2010, Naturia 2010, Islam 2003). According to Naturia (2010), each bird may specialize in a particular prey. All these findings suggest that $H$. smyrnensis is more voracious and take different types of food whatever comes around. Soud et al. (2010) reported that the main cause of diet selection might be due to the opportunistic feeding habit of $H$. smyrnensis to maintain the daily food requirements.

Food preference: H. smyrnensis preferred height to prey on fishes. Overall the highest and lowest preferences of $H$. smyrnensis were found to be fry of Rohu (Labeo rohita) and Caddies Fly (Agapetus sp.) $(\mathrm{n}=193)$ respectively (Fig. 1).

The highest and lowest preferences of $H$. smyrnensis were Freshwater Shrimp (Macrobrachium sp.) and Caddies Fly respectively (Fig.1) among arthropods $(\mathrm{n}=70)$. It did not prey on larvae, pupae and nymphs of various arthropods, but preyed on Grass hopper (Poceilocerus sp.), Mud Crab (Spiralothelphus sp.) and Cockroach (Periplanata americana). It preyed on some small arthropods also like, aquatic bugs and beetles, may fly, caddies fly and freshwater shrimp in the present study. Naturia (2010) reported that they hunt grasshoppers, beetles, termites, scorpions and centipedes. Burton (1998) reported that the preying was insects mainly grasshoppers, beetles and ants in Malaysia. According to Animal Diversity (2007), the birds are taking arthropods like locusts, crickets, beetles, mantises, ants, termites, dragonflies, grasshoppers, Ocypode and Paratelphusa crabs, scorpions and centipedes. Wildlife Introduction (2009), Avian Web (2010) and Flickr (2010) reported that, the White-throated Kingfisher mainly hunt large insects, earthworms, rodents, snakes, fish and frogs. It is also reported to eat tired migratory passerine birds like Chiffchaffs where the opportunity arises (Avian Web 2010, Flickr 2010). Asokan et al. (2009) observed that H. smyrnensis preys primarily $83 \%$ on arthropods in southern India. Ali and Ripley (1983) reported that the preying insects consisted of grasshoppers, crickets, mantises, scarab, and other beetles including the aquatic Dysticidae; ants and winged termites emerging from the ground, locusts and dragonflies, crabs, Paratelphusa in flooded paddy fields inland; scorpions and centipedes. 
Among the fishes, the highest and lowest preferences of these were fry of Rohu and Silver Barb (Puntius gonionotus) $(\mathrm{n}=118)$ respectively (Fig. 1). The preferences of fishes were generally depended upon the availability in the water bodies.

When H. smyrnensis got any chance to prey Skipper Frog (Euphlyctis cyanophlyctis) $(\mathrm{n}=3$ ) and House Lizard (Hemidactylus flaviviridis) $(\mathrm{n}=2)$, they also preyed on them. After preying an amphibian or reptile, they did not take any other food immediate after. The amphibians and reptiles form an important component of diet of $H$. smyrnensis in different parts of the world as mentioned earlier (e.g., Soud et al. 2010, Wikipedia 2010, Wildlife Introduction 2009, Avian Web 2010 and Flickr 2010).

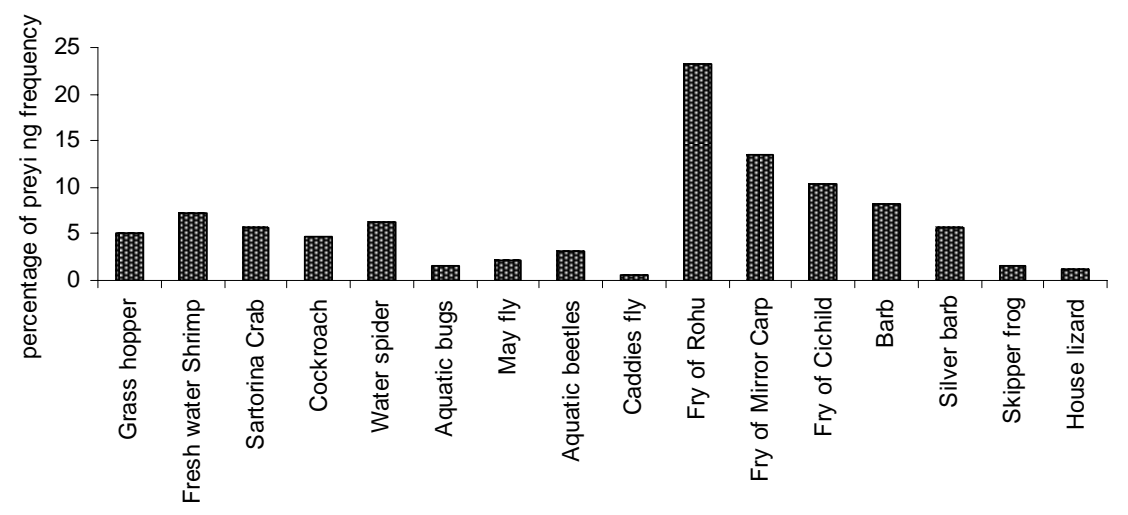

Fig. 1. Preference of different food items preyed by Halcyon smyrnensis.

Food preference according to Orders: Among the total food items, the highest and lowest preferences were the species belonged to the Order Cypriniformes (50.7\%) and Lecertilia (1.1\%) (Table 1$)$.

Among arthropods, they highly preferred the species belonged to Order Decapoda (20\%) followed by Arachnida (17\%), Orthoptera (14\%), Brachyura (15.7\%), Dictyoptera (13\%), Coleoptera (8.7\%), Ephemeroptera (5.8\%), Hemiptera (4.4\%) and Trichoptera (1.4\%). Asokan et al. (2009) observed that it preys Coleopteran (22\%) mainly followed by Hemiptera (17\%), Hymenoptera (15\%) and Orthoptera (14\%) in southern India. Yahya (2001) and Asokan et al. (2009) supported the findings of Mukherjee (1975). Among the Orders of fishes, the highest preference was Cypriniformes (83\%) followed by Perciformes (17\%).

Food preference according to Family: Overall the highest preference was the species belonged to the Family Cyprinidae (50.7\%) and lowest was Glossosomatidae (0.5\%) (Table 1). Among the arthropods, these were Astacidae 
$(20 \%)$ and Glossosomatidae $(1.5 \%)$ respectively and among the fishes, the highest was Cypriniidae Family .

Size of the food items: $H$. smyrnensis preyed on different sized animals which varied according to length and breadth. The length varied from 2.0 to $12.3 \mathrm{~cm}$ $(4.6 \pm 2.3, \mathrm{n}=94)$ (Table 2).

Table 2. Size of the food items preyed by Halcyon smyrnensis.

\begin{tabular}{lllll}
\hline $\begin{array}{l}\text { Food items of } H . \\
\text { smyrnensis }\end{array}$ & $\begin{array}{l}\text { Length } \\
(\mathrm{cm})\end{array}$ & $\begin{array}{l}\text { Average } \pm \\
\text { SD }\end{array}$ & Breadth $(\mathrm{cm})$ & $\begin{array}{l}\text { Average } \pm \\
\text { SD }\end{array}$ \\
\hline Grass hopper & $3.7-6.5$ & $5.9 \pm 0.8(\mathrm{n}=5)$ & $0.8-1.4$ & $0.9 \pm 0.2(\mathrm{n}=5)$ \\
Shrimp & $3.6-6.3$ & $5.7 \pm 1.1(\mathrm{n}=14)$ & $0.8-1.7$ & $1.3 \pm 0.3(\mathrm{n}=10)$ \\
Sartorina Crab & $3.1-4.2$ & $2.9 \pm 0.4(\mathrm{n}=5)$ & $4.8-5.6$ & $4.7 \pm 0.4(\mathrm{n}=5)$ \\
Cockroach & $3.8-4.7$ & $3.7 \pm 0.8(\mathrm{n}=5)$ & $2.4-2.9$ & $1.9 \pm 0.4(\mathrm{n}=5)$ \\
Water spider & $2.0-2.6$ & $2.2 \pm 0.3(\mathrm{n}=5)$ & $1.3-1.8$ & $1.6 \pm 0.7(\mathrm{n}=5)$ \\
Aquatic Bugs & $2.2-2.7$ & $2.6 \pm 0.3(\mathrm{n}=5)$ & $1.0-1.4$ & $1.3 \pm 0.2(\mathrm{n}=5)$ \\
May fly & $2.3-2.5$ & $2.4 \pm 0.1(\mathrm{n}=5)$ & $0.2-0.4$ & $0.3 \pm 0.1(\mathrm{n}=5)$ \\
Aquatic Beetles & $3.5-4.0$ & $3.8 \pm 0.3(\mathrm{n}=5)$ & $2.5-2.8$ & $2.6 \pm 0.3(\mathrm{n}=5)$ \\
Caddies fly & 0.6 & $0.6(\mathrm{n}=1)$ & 0.1 & $0.1(\mathrm{n}=1)$ \\
Fry of Rohu & $7.5-10.6$ & $9.4 \pm 0.9(\mathrm{n}=10)$ & $1.8-2.8$ & $2.3 \pm 0.3(\mathrm{n}=10)$ \\
Fry of Mirror Carp & $7.6-11.8$ & $9.5 \pm 1.3(\mathrm{n}=5)$ & $1.9-2.9$ & $2.5 \pm 0.4(\mathrm{n}=5)$ \\
Fry of Cichlid & $4.8-10.7$ & $3.5 \pm 0.5(\mathrm{n}=10)$ & $2.9-5.6$ & $1.8 \pm 0.1(\mathrm{n}=10)$ \\
Barb & $5.1-6.4$ & $5 \pm 0.9(\mathrm{n}=10)$ & $2.7-4.7$ & $3.2 \pm 0.3(\mathrm{n}=10)$ \\
Silver barb & $2.6-6.1$ & $4.6 \pm 1.7(\mathrm{n}=5)$ & $1.8-4.1$ & $3.4 \pm 0.9(\mathrm{n}=5)$ \\
Skipper frog & $3.4-5.2$ & $3.3 \pm 0.3(\mathrm{n}=2)$ & $2.3-3.2$ & $1.8 \pm 0.6(\mathrm{n}=2)$ \\
House lizard & $11.2-12.3$ & $6.8 \pm 0.2(\mathrm{n}=2)$ & $1.4-1.9$ & $1.3 \pm 0.4(\mathrm{n}=2)$ \\
\hline
\end{tabular}

Among the arthropods, it varied from 2.0 to $6.5 \mathrm{~cm}(3.4 \pm 1.9, \mathrm{n}=50)$ and fishes it was 2.6 to $11.8 \mathrm{~cm}(6.4 \pm 3.1, \mathrm{n}=40)$. Other than arthropods and fishes, it also preyed on amphibians and reptiles, the length of which varied from 3.4 to $12.3 \mathrm{~cm}(5.1 \pm 2.5, \mathrm{n}=4)$.

The length of all the food items took by $H$. smyrnensis was divided into two categories-longer than $5 \mathrm{~cm}$ and smaller than $5 \mathrm{~cm}$. They highly preferred to prey the food items having the length smaller than $5 \mathrm{~cm}$ (53.5\%). The British Wildlife Society (2011) and Animal Corner (2011) mentioned that they fed on aquatic insects and small fishes ranging from $1(2.54 \mathrm{~cm})$ to 5 inches $(12.7 \mathrm{~cm})$ long. On the other hand, it takes the foods up to $65 \mathrm{~cm}$ long (Naturia 2010). Soud et al. (2010) reported that an incident of predation on Common Wolf Snake Lycodon aulicus (Family: Colubridae) of $300 \mathrm{~mm}$ length by $H$. smyrnensis was observed in the Eco-forest region of Assam University campus. Such differences can easily be explained as the birds try to take those fishes that are available in their water bodies and also the sizes they can handle. Moreover, it is also true that any animal sometimes take usual food items under compulsion or under certain circumstances. As such, taking of snakes is unusual phenomenon rather than regular practice. 
The breadth of all the food items took by $H$. smyrnensis varied from 0.2 to $5.6 \mathrm{~cm}(2.1 \pm 1.1, \mathrm{n}=94)$. The breadth of the arthropods varied from 0.2 to 5.6 $\mathrm{cm}(1.9 \pm 1.3, \mathrm{n}=50)$ and fishes from 1.4 to $5.6 \mathrm{~cm}(2.8 \pm 0.7, \mathrm{n}=40)$. Other than arthropods and fishes, it also preyed on amphibians and reptiles the breadth of which varied from 1.4 to $3.2 \mathrm{~cm}(1.6 \pm 0.4, \mathrm{n}=4)$.

The breadth of all the food items was divided into two categories-longer than $2 \mathrm{~cm}$ and smaller than $2 \mathrm{~cm}$. They highly preferred to prey the food items having the breadth longer than $2 \mathrm{~cm}(52.1 \%)$.

Habitat and feeding habits of the food items: The birds highly preferred to prey surface dweller species (85.8\%) which had omnivorous feeding habits $(n=193)$ (Table 1). The birds sometimes took deepwater fishes when they came to surface for some physiological reasons. The kingfishers are not deep divers and do not spend significant amounts of time underwater (Ali and Ripley 1983, Anderton and Rassmussen 2005).

Height used during preying: During preying, H. smyrnensis used 0.3 to 2.25 $\mathrm{m}$ height $(1.71 \pm 0.7, \mathrm{n}=10)$ (Fig. 2). The highest preference was recorded from $0.9 \mathrm{~m}(32 \%)$ and the lowest was $2.25 \mathrm{~m}$.

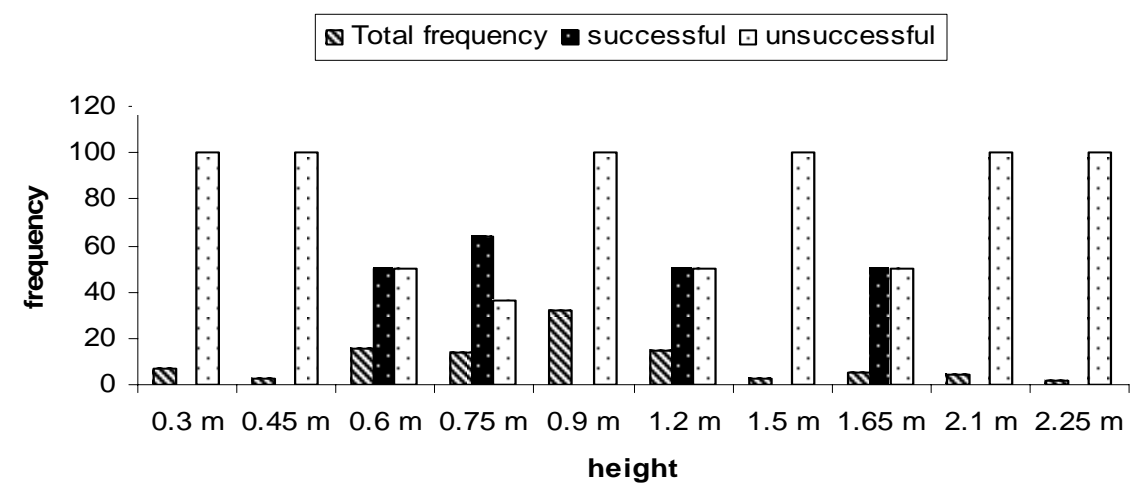

Fig. 2. Preying height used by Halcyon smyrnensis.

According to Avian Web (2010), it was up to $10 \mathrm{~m}$ above from the ground. The Cerulean Kingfisher (Alcedo coerulescens) is frequently seen diving from a hovering position at 2 to $4 \mathrm{~m}$ above the water surface at coastal areas of Java, Madura, Bali and the western Lesser Sundas in Indonesia (Balen 1998). With perch plunge method, a bird will increase its perch height with an increased depth of water (Cramp et al. 1988). They preferred certain heights from where it could be easy for them to prey. It was also found that the platform varied from one water body to another from where the bird plunged. 
In case of unsuccessful attempt of perch plunge, the highest frequency was noticed on $0.75 \mathrm{~m}$ height $(63.63 \%)$. No unsuccessful frequency was found when it preyed on from a height of $0.3 \mathrm{~m}, 0.45 \mathrm{~m}, 0.9 \mathrm{~m}, 1.5 \mathrm{~m}$ and $2.25 \mathrm{~m}$. During skimming, it used $0.3 \mathrm{~m}$ to $0.9 \mathrm{~m}(0.5 \mathrm{~m} \pm 0.2, \mathrm{n}=08)$ height.

Spending time to catch a prey: After noticing suitable food item, they waited for a while and targeted the food items before catching. They took different times ( $9 \mathrm{sec}$ to $917 \mathrm{sec}$, median $108, \mathrm{n}=10$ ) to catch a food item. They spent a longer period for snatching prey (Avian Web 2010).

Sometimes the attempt was successful (70 \%) sometimes not. The targeted time was not related with the height. Sometimes the height was less and the targeted time was more but the attempt was unsuccessful. On the contrary, when the height was more and the targeted time was less the attempt was successful. It was depended on just its concentration and attention during preying.

Table 3. Spending time to catch a prey by Halcyon smyrnensis.

\begin{tabular}{|c|c|c|c|}
\hline Height $(\mathrm{m})$ & Target (time) & unsuccessful & successful \\
\hline 0.30 & $15 \mathrm{sec}$ & - & + \\
\hline 0.45 & $33 \mathrm{sec}$ & - & + \\
\hline 0.60 & $1 \mathrm{~min} 21 \mathrm{sec}(81 \mathrm{sec})$ & + & - \\
\hline 0.75 & $12 \min 01 \mathrm{sec}(721 \mathrm{sec})$ & + & - \\
\hline 0.90 & $52 \mathrm{sec}$ & - & + \\
\hline 1.20 & $11 \mathrm{~min} 12 \mathrm{sec}(672 \mathrm{sec})$ & + & - \\
\hline 1.50 & $2 \min 15 \mathrm{sec}(135 \mathrm{sec})$ & - & + \\
\hline 1.65 & $1 \mathrm{~min}(60 \mathrm{sec})$ & - & + \\
\hline 2.10 & $15 \min 17 \mathrm{sec}(917 \mathrm{sec})$ & - & + \\
\hline 2.25 & $12 \min 04 \mathrm{sec}(724 \mathrm{sec})$ & - & + \\
\hline 0.30 & $10 \min 18 \mathrm{sec}(618 \mathrm{sec})$ & + & + \\
\hline 0.45 & $35 \mathrm{sec}$ & + & - \\
\hline 0.60 & $09 \mathrm{sec}$ & - & + \\
\hline 0.75 & $3 \mathrm{~min} 12 \mathrm{sec}(192 \mathrm{sec})$ & - & + \\
\hline
\end{tabular}

Spending time to engulf a prey: After catching a prey item, they took different times to engulf a prey. Sometimes, they engulfed immediately after catching the prey. Sometimes they hold the prey item at their beak for a while ( 2 sec to 1830 sec, median $5, \mathrm{n}=18$ ) before engulfing.

They took more time comparatively to engulf a fish (median 10, $n=10$ ) because the size of the fish item was comparatively larger than other food items. This is a natural phenomenon; birds will take more time to engulf a large sized fishes (Mirror Carp) than small one (Silver Barb) or any other prey of small sizes (Grass hopper) ( 2 to $10 \mathrm{sec}, 4.5 \pm 2.4, \mathrm{n}=8$ ) than other smaller one. 
Thus, when they preyed on an arthropod they engulfed it immediately after catching. Even the engulfing time of fishes varied according to size of fishes. They always engulfed the foods after sitting on the perch from where they preyed on. When they engulfed any food items like fish or any other large arthropods, they engulfed it head first. If they caught it at tail or middle of the body, they turned it into head and finally engulfed it.

Use of perching places during preying: They used various perching places during preying (Fig. 3). It highly used bamboo found in the water body or at the side of water hyacinth in the water bodies during preying of all types of food items (65.9\%). According to Wikipedia (2010), it perches conspicuously on wires or other exposed perches within its territory. The Kingfisher perches on dead branches (Islam 2003) during preying.

Table 4. Spending time to engulf a prey by Halcyon smyrnensis.

\begin{tabular}{lcl}
\hline Food items of H. smyrnensis & $\begin{array}{c}\text { Size } \\
\text { (length } \times \text { breadth) }(\mathrm{cm})\end{array}$ & Engulfing time \\
\hline Fry of Rohu, Labeo rohita & $14 \times 2.5$ & $9 \mathrm{sec}$ \\
& $12.7 \times 1.8$ & $30 \mathrm{~min} 30 \mathrm{sec}$ (1830 sec) \\
& $11.7 \times 1.7$ & $4 \mathrm{sec}$ \\
& $10.2 \times 1.8$ & $10 \mathrm{sec}$ \\
Fry of Mirror Carp, Cyprinus carpio & $13.2 \times 2.1$ & $9 \mathrm{~min} 3 \mathrm{sec}(543 \mathrm{sec})$ \\
Barb, Puntius spp & $16.4 \times 4.9$ & $2 \mathrm{~min} 20 \mathrm{sec}(140 \mathrm{sec})$ \\
Silver Barb, Puntius gonionotus & $5.08 \times 4.6$ & $3 \mathrm{sec}$ \\
Fry of Cichlid, Oreocromis sp. & $5.2 \times 3.8$ & $2 \mathrm{sec}$ \\
& $5.1 \times 3.1$ & $1 \mathrm{~min} 8 \mathrm{sec}(68 \mathrm{sec})$ \\
Skipper Frog, Euphlyctis cyanophlyctis & $10.7 \times 5.6$ & $28 \mathrm{~min} 01 \mathrm{sec}(1681 \mathrm{sec})$ \\
House Lizard, Hemidactylus flaviviridis & $3.81 \times 2.7$ & $3 \mathrm{sec}$ \\
Grass hopper, Poecilocerus sp. & $11.5 \times 1.6$ & $4 \mathrm{sec}$ \\
& $2.5 \times 0.6$ & $2 \mathrm{sec}$ \\
Fresh Water Shrimp, Macrobrachium sp. & $2.8 \times 0.8$ & $5 \mathrm{sec}$ \\
& $3.3 \times 1.2$ & $3 \mathrm{sec}$ \\
Sartorina Crab, Sartoriana spinigera & $2.4 \pm 7.4$ & $10 \mathrm{sec}$ \\
Cockroach, Periplanata americana & $3.7 \times 5.2$ & $4 \mathrm{sec}$ \\
\hline
\end{tabular}

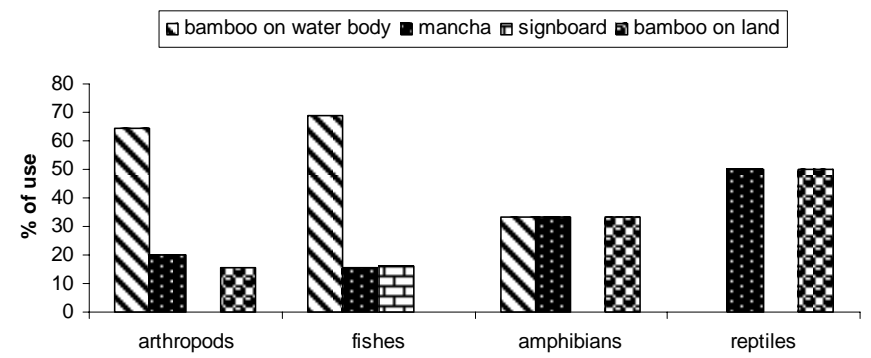

Fig. 3. Use of perching places during preying on food items by Halcyon smyrnensis. 
Preying and feeding activities: During preying, they perched on the branches of trees or bamboo over or close to the water or land. For preying, they dived into shallow or deep water or even into grass and vegetation. They also preyed on flying insects. After catching the prey, they flew straight out of the water with its prey in their bills. It came back to same perch in most of the cases. The prey was placed crosswise in their bill, then the bird bit the head of the caught item on tree branch or supported by moving its (Kingfisher) head on left and right alternatively, then it swallowed the food item headfirst. Islam and Kamruzzaman (2008) reported that it foraged by scanning the water surface from its low perch and plunged headlong into water to hunt. For preying, they dived into shallow or deep water or even into grass and vegetation. Such habitat was also reported by Naturia (2010). They also found preying flying insects. Swarming termites may also be caught in flight (Naturia 2010). It is often to be seen perched on a stick, branch, post or dead tree overlooking a ditch or pool, watching intently for prey (Woodcock 1980). Islam and Kamruzzaman (2008) reported that it foraged by scanning the ground or water from its perch on fence-posts, cables or branches. It was found that at the perch, they adjusted the prey at cross-wise but caught it at tail or middle of the body and beaten against the perch for several times until death. Ali and Ripley (1983) reported the fish was held crosswise in the bill.

Feeding territory: They found highly territorial birds. They fiercely defended their feeding grounds. It was also reported that it was defended even from their mates and offspring. They hunt alone. Sometimes one to three $H$. smyrnensis used same feeding grounds. It perched as much as 6 to $30 \mathrm{~m}(20.5 \pm 6.7, \mathrm{n}=10)$ apart from each other. Naturia (2010) mentioned that $H$. smyrnensis hunt alone, but where hunting is good, they might perch as close as $100 \mathrm{~m}$ apart without showing much hostility. Ali et al. (2010a) reported that the scanning activity was the most time consuming activity for White-throated Kingfishers. The Whitethroated Kingfisher is a sit-and-wait predator and so they spent the majority of their daytime for searching the prey. Scanning is a widespread behaviour amongst predatory birds (Ettinger and King 1980, Mahabal 1991, Sivakumaran and Thiyagesan 2003). It mostly preferred to stay in their feeding sites $(80.7 \%, \mathrm{n}$ =63) after preying.

\section{CONCLUSION}

The White-throated Kingfisher is a resident bird of the wetlands of Bangladesh. They are highly territorial birds and feed on a variety of arthropods, fishes, frogs and house lizard. They are beneficial to agriculturists as they take a wide variety of insects. They even take flying insects. Thus they keep check the populations of various insect pests of crops. So they are also known as insectivorous birds. They feed on various sized food items which they can 
handle. They take those types of animals which are available on their surroundings. They used a certain heights during preying from which they can easily prey on. They engulfed the prey immediately after catching when the prey item was small and they could easily handle but if the prey item was so large they took some time to engulf it because they had to loss more energy to catch it. After taking some rest they engulfed. They always engulfed the foods after sitting on the perch from where they preyed on. Now the aquatic bodies of our country are declining because of the human needs (for housing, industry, roads etc.). It should take necessary measures to conserve the kingfishers' suitable environment otherwise it would fall in threatened list.

Acknowledgements: The authors are grateful to the Ministry of Science, Information and Communication Technology for funding the research. We express our heartiest gratitude to Mr. Tauhid Uddin Ahmed, Ex-Principal Scientific Officer, IECDR, Mohakhali, Dhaka, Bangladesh for making helpful and constructive comments to enrich this manuscript and for identifying the arthropods.

\section{LITERATURE CITED}

*ANDERTON, J. and RASSMUSSEN, P. 2005. Birds of South Asia. The Ripley Guide. Vols. 1 and 2. Barcelona: Smithsonian Institution and Lynx Editions.

${ }^{*}$ FRY, C.H., FRY, K. and HARRIS, A. 1992. Kingfishers, bee-eaters and rollers. London: Christopher Helm, London.

AHSAN, M.F. and SAEED, M.A. 1990. Food and feeding habits of some piscivorous birds of Chittagong. J. Asiat. Soc. Bangladesh, Sci. 16 (1): 39-45.

ALI, A.M.S., ASOKAN, S. and MANIKANNAN, R. 2010a. Habitat-related Density and Activity Patterns of the White-breasted Kingfisher Halcyon smyrnensis in Cauvery Delta, Southern India. Podoces. 5(1):54-62.

ALI, S. 1996. The Book of Indian Birds. 12th Revised and enlarged edition. Bombay Natural History Society, Mumbai. pp. 345.

ALI, S. and RIPLEY, S.D. 1983. Handbook of the birds of India and Pakistan. Vol.4. Oxford University Press, New York. pp. 265.

ANIMAL CORNER. 2011. Available at: http://www.animalcorner.co.uk/britishwildlife/ kingfisher. html. Accessed date 18-01-2011.

ANIMAL DIVERSITY. 2007. Available at http://animaldiversity.ummz.umich.edu/site/ accounts/ information/ Halcyon_smyrnensis.html. Accessed date 15-10-2007.

ARKIVE. 2010b. Available at http://www.arkive.org/kingfisher/Halcyon-smyrnensis/info. html. Accessed date: 10-09-10.

ASOKAN, S., ALI, A.M.S. and MANIKANNAN, R. 2009. Diet of three insectivorous birds in Nagapattinam District, Tamil Nadu, India - a preliminary study. J. Threat. Taxa. 1(6): 27-33.

AVIAN WEB. 2010. Available at http://www.avianweb.com/whitethroatedkingfishers.html. Accessed date: $07-10-2010$.

BALEN, S. V. 1998. Hovering of Cerulean Kingfishers Alcedo coerulescens. Forktail. 13: 121. 
BORDER D.J., DELONG D.M. and TRIPLEHORN C.A. 1981. An introduction of the study of Insects. $5^{\text {th }}$ ed. Saunders College Publishing, New York and London. $5^{\text {th }}$ Ed. pp. 826.

BRITISH WILDLIFE SOCIETY. 2011. Available at: http://britishwildlifeandnature.wikia.com/ wiki/ Kingfisher. Accessed date 10-10-2011.

CRAMP, S., DOUTHWAITE, R., REYER, K. and WESTERTURP. 1988. Ceryle rudis (Linnaeus). Pied Kingfisher. In: H. Fry, S. Keith, E. Urban, eds. The Birds of Africa. Vol III, San Diego: Academic Press. pp. 299-302.

ECOINDIA 2008. Available at http://www.ecoindia.com/animals/birds/common-kingfisher. html. Accessed date: 05-07-2008.

ETTINGER A.O. and KING J.R. 1980. Time and energy budgets of the Willow Flycatcher (Empidonax traillii) during the breeding season. Auk. 97: 533 -546.

EWANS, M. 1989. Bharatpur Bird Paradise. Lustre Press Pvt. Ltd., New Delhi. pp. 144.

FLICKR. 2010. Available at http://www.flickr.com/groups/kingfishers/discuss/721576/ 17089512032/Accessed date: 07-10-2010.

GRIMMETT, R., INSKIPP, C. and INSKIPP, T. 1998. Birds of the Indian Subcontinent. Oxford University Press, New Delhi. pp. 888.

ISLAM, M.A. 2003. Kingfisher. In: Islam, S., Miah, S., Ahmed, W., Chowdhury, A.M., Rahman, S.M.M., Siddiqui, K. and Kabir, S.M.H. (eds). Banglapedia. National Encyclopedia of Bangladesh. Vol. 6. Asiatic Society of Bangladesh, Dhaka. pp. 110-112.

ISLAM, M.A. and KAMRUZZAMAN, M. 2008. Halcyon smyrnensis. In: Siddiqui, K.U., Islam, M.A., Kabir, S.M.H., Ahmad, M., Ahmed, A.T.A, Rahman, A.K.M., Haque, E.U., Ahmed, Z.U., Begum, Z.N.T., Hassan, M.A., Khondker, M. and Rahman, M.M. (eds.). Encyclopedia of Flora and Fauna of Bangladesh. Vol. 26. Birds. Asiatic Society of Bangladesh, Dhaka. pp. 75 -76.

ISLAM, M.A., KHAN, M.M.H., KABIR, M.M., SOLHOY, T., JORDAR, N.B. and FEEROZ, M.M. 1999. Winter birds of the Sundarbans, Bangladesh. Ecoprint. 6(1): 41-49.

JERDON, T.C. 1982. The Birds of India. Vol. 1. The Military orphan press, Calcutta. pp. xlv+535.

MAHABAL, A. 1991. Activity-time budget of Indian Myna Acridotheres tristis (Linnaeus) during the breeding season. J. Bom. Nat. His. Soc. 90: 96-97.

MUKHERJEE, A.K. 1975. Food-habits of water-birds of the Sundarban, 24 Paraganas District, West Bengal. India-V. J. Bombay Nat. Hist. Soc. 72: 85-109.

NATURIA, 2010. Available at http://www.naturia.per.sg/buloh/birds/Halcyon_smyrnensis. htm. Accessed date: 10-09-2010.

OOMMEN M. and ANDREWS M.I. 1998. Food and feeding habits of the White-breasted Kingfisher Halcyon smyrnensis. In: Dhindsa M.S., Shyamsunder P. \& Parasharya B.M. (Eds.), Birds in Agriculture Ecosystem, Society for Applied Ornithology (India). pp. 132-136.

OOMMEN, M. and ANDREWS, M. I. 1996. Awakening, roosting and vocalization behaviour of the White-breasted Kingfisher Halcyon smyrnensis fusca (Boddaert). Pavo. 34: 43-46.

RAHMAN, A.K.A. 1989. Freshwater fishes of Bangladesh. The Zoological society of Bangladesh. University of Dhaka, Dhaka. pp. 364.

REZA, A.H.M.A., FEROOZ, M.M., ISLAM, M.A. and KABIR, M.M. 2003. Status and density of Kingfishers (Family: Alcedinidae, Halcyonidae and Cerylidae) in the Sunderbans mangroves forest, Bangladesh. Bangladesh J. Life Sci. 15(1): 55-60.

ROBERTS T.J. and PRIDDY C. 1965. Food of the White-breasted Kingfisher Halcyon smyrnensis (Linnaeus). J. Bom. Nat. His. Soc. 62(1): 152153.

ROZA T. 1995. Crab-eating by White-breasted Kingfisher Halcyon smyrnensis (Linn.). J. Bom. Nat. His. Soc. 92(1): 121. 
SARKER, S.U. 1989. Fish eating wildlife and some fishes of the Sundarbans, Bangladesh. J. Noami. 6(1 and 2): 17-29.

SIVAKUMARAN, N. and THIYAGESAN K. 2003. Population, diurnal activity patterns and feeding ecology of the Indian Roller (Coracias benghalensis). Zoo's Print J. 18: 1091-1095.

SOUD R., MAZUMDAR K. and GUPTA A. 2010. Predation by White-throated Kingfisher Halcyon smyrnensis on Common wolf Snake Lycodon aulicus (Linnaeus). Ne. Bio. 1(1): 53-54.

WHISTLER, H. 1986. Handbook of Indian Birds. Cosmo Publications, New Delhi. pp. xxiv +438 .

WIKIPEDIA. 2010. Available at http://en.wikipedia.org/wiki/Common_Kingfisher. Accessed date 15$10-2010$.

WILDLIFE INTRODUCTION. 2009. http://wildlifeintroduction.blogspot.com/2009/03/whitethroated-kingfisher. html. Accessed date: 13-03-2009.

WOODCOCK, M. 1980. Birds of the Indian Sub-continent including India, Pakistan, Bangladesh, Sri Lanka and Nepal. Harper Collins Publishers, Hongkong. pp. 176.

YAHYA, H.S. 2001. Feeding habits of the White-breasted Kingfisher Halcyon smyrnensis (Linn.) Family Alcedinidae. J. Bom. Nat. Hist. Soc. 98:450-451.

YAHYA, H.S. and YASMIN, S. 1991. Earthworms in the dietary of the White-breasted Kingfisher Halcyon smyrnensis (Linn.). J. Bombay Nat. Hist. Soc. 88: 454.

*Paper was not originally seen.

(Manuscript received on 10 February, 2014; revised on 28 September, 2014) 